\title{
Students' views on mathematics in single-sex and coed classrooms in Ghana
}

\author{
Emmanuel Adu-tutu Bofah, Markku S Hannula \\ Department of Teacher Education, Unversity of Helsinki, Helsinki, Finland \\ For correspondence : emmanuel.bofah@helsinki.fi
}

\begin{abstract}
In this study, we investigated students' views on themselves as learners of mathematics as a function of school-by-sex $(\mathrm{N}=2034, \mathrm{MAge}=18.49, \mathrm{SDAge}=1.25 ; 12$ th-grade; $58.2 \%$ girls $)$. Using latent variable Structural Equation Modeling (SEM), the measurement and structural equivalence as well as the equality of latent means of scores across single-sex and coed schools were tested. Findings regarding the latent mean differences revealed that girls in single-sex schools had significantly higher mathematics self-confidence than did students' in coed schools. Girls in coed schools had significantly lower mathematics self-concepts than did boys in single-sex, girls in single-sex and boys in coed schools. Girls in single-sex schools had significantly higher family encouragement than students' in all other school types. Moreover, a more complex dynamics were found on the teacher quality variate. This paper argues for a deeper understanding of sex-school interaction and of possible causes of students' views on mathematics.
\end{abstract}

Keywords: Single-sex coed schools, Gender, Mathematics self-confidence, Mathematics self-concept, Teacher quality, Family encouragement.

\section{Introduction}

Beliefs, values, attitudes, self-confidence, and motivation plays a vital role on how students approach and process information. These factors can either help or impede the learning of mathematics (Bofah \& Hannula, 2015a; Grootenboer \& Hemmings, 2007; Hannula, 2015). Knowing the influence of these factors, understanding students' beliefs, can provide insight into their learning and motivation. Studies have shown that gender influences students' mathematics self-concept, mathematics selfconfidence, and the perceived usefulness of mathematics (e.g., Belcher et al. 2006).

Single-sex schools are common in many countries associated with Great Britain (e.g., the Commonwealth nations such as Australia, Canada, New Zealand, Nigeria, Kenya, Ghana, South Africa and others), the United States, and in the Arab world (e.g., Saudi Arabia) (Lee \& Bryk 1986; Mael et al. 2005; Marsh et al. 2013; Smithers and Robinson 2006). Single-sex schools are schools where males or females attend school solely with members of their own sex. Such single-sex settings can involve the whole school or a single class, program or stream within the school. The rarity of these types of schools in such locations has meant little research is available of single-sex and coed schools because such research has been limited to areas where those school types exist. In addition, much of the available research on secondary-level single-sex and coed schooling has focused on students' attitudes about the social and psychological environments of the schools rather than on specific domains; such as mathematics (Belcher et al. 2006; Lee and Bryk 1986). Consequently, because, singlesex schools are a worldwide phenomenon, the different educational systems and variations in cultural contexts associated with these countries limit generalizations from such studies (Bigler and Signorella 2011; Signorella, Hayes, and Li 2013)). 
Over the past two decades, preferring single-sex schools over coed schools has been one strategy Ghana has employed in an attempt to change the learning environment to one more favorable for girls as well as to promote gender equity, improve school attendance, and attitude towards mathematics and science, particularly for girls.

Research of single-sex schools has reported positive outcomes (Duros, 1996; Rennie and Parker 1997). Notable outcomes in single-sex schools include improved behavior, higher achievement, increased student self-confidence and self-concept, fewer school dropouts, an enhanced social climate and improved student and parent attitudes toward schooling. However, the real impact of single-sex schools cannot be determined (Marsh, 1989) unless variables such as prior achievement, socioeconomic status (SES), parental support, school traditions, and homogeneity in school types, are controlled (Hayes et al. 2011; Nagengast et al. 2013). Moreover, immediate factors, such as expectations and situational pressures, as well as social and cultural patterns on gender, shape school and gender-related behavior (Deaux and Major 1987).

In a review of studies on single-sex schools in Australia, the U.S., Canada, New Zealand, Ireland, and the United Kingdom, Smithers and Robinson (2006) could not conclude which school type was advantageous over the other. They concluded that it is for providers to offer the school type based on circumstances, and for parents to choose the best school type for their children.

With no clear advantage of one school type of the other, the purpose of the study is to examine students' "Views on Mathematics (VOM)" in single-sex and coed schools in Ghana. First, we will examine the psychometric properties (factor structure, reliabilities, method effect, and measurement invariance-sex-by-school) of the VOM constructs (e.g. mathematics self-confidence, mathematics self-concept, family encouragement, and teacher quality) across the school type. Second, to investigate sex- and school-related latent mean differences across the VOM constructs.

\section{Background to the Study}

\section{Self-beliefs}

This paper begins with Schoenfeld (1985, p. 44) notion that "belief is one's mathematical worldview". Self-beliefs such as self-confidence and self-concept in mathematics learning have for some time consistently emerged as an important variate in sex-related differences in mathematics (Belcher et al. 2006; Marsh et al. 2013; Norton and Rennie 1998). In this paper, self-concept is defined in line with Purkey (1970) and Rosenberg's (1986) notion of self-concept as the totality of a complex, organized, and dynamic system of beliefs, attitudes and opinions that each individual holds, having reference to himself as the object. On the other hand, we define "mathematics self-confidence" as "the anticipation of successfully mastering challenges, more generally, the belief that students can make things happen in accord with inner wishes" (Rosenberg 1986, p. 37). Both mathematics self-concept and selfconfidence comprise a set of attitudes, beliefs, and perceptions held by students about their academic performance. Self-confidence is a specific form of self-concept, and both are known to be highly influenced by a frame of reference effect-the context within which they evaluate themselves or standards against which to judge one's own accomplishments and failures, (e.g., Bong and Skaalvik 2003) such that, for instance a students' self-concept responses will be based on comparisons with other students' in the same school or class (Marsh et al. 2013). Thus, for self-beliefs (e.g., self-concept and self-confidence) "...students use normative judgments about their ability and social comparison processes with reference to their peers, but also internal comparisons of their performance in one academic domain relative to other academic domains" (Parker et al. 2013, p. 4).

Gender differences in mathematics self-confidence and mathematics self-concept have received considerable attention, with girls reporting lower self-confidence and lower self-concept about their 
mathematics abilities (Asante 2012; McGraw et al. 2006). In a meta-analysis of the Trends in International Mathematics and Science Study (TIMSS) and the Program for International Student Assessment (PISA) data, representing 493,495 students aged 14 to 16 from 69 countries, Else-Quest et al. (2010) found, on average, very small gender difference in tuts affective dispositions, with girls showing significantly less motivation and less confidence in their mathematical abilities.

Studies of single-sex schools have reported mixed results with regard to self-concept (Mael et al. 2005). Marsh et al. (2013) analyzing TIMSS-2007 motivational constructs, found that self-concept was higher for boys in Anglo-Saxon countries and higher for girls in Arab countries whereby school type is predominantly single-sex. Lee and Bryk (1986), also found that students in single-sex schools have higher self-concepts than do those in coed schools. A re-analysis of Lee and Bryk's data found no differences in school type (single-sex or coed) when other variables are controlled (Marsh 1989). However, other studies have also found higher self-concept (e.g., Riordan 1990) and self-confidence (e.g., Mallam 1993; Rowe 1988) for girls in only a single-sex environment.

In a study of students' attitudes towards mathematics in Ghana, Eshun (2004) and Nyala (2010) found that girls in single-sex schools reported the highest mathematics confidence, when compared to boys in single-sex schools and to both sexes in coed schools. Boys in coed schools reported lower mathematics confidence than did boys in single-sex schools. Overall, boys in the coed school reported the lowest mathematics confidence. Examining ninth-grade students' attitudes toward learning mathematics (e.g. confidence), science and school climate perceptions, Brown and Ronau (2012) found no significant difference in males' or females' attitudes toward learning mathematics or science, even when segregated into single-sex or coed classes. In Kenya, Githua and Mwangi (2003) found higher mathematics self-confidence and higher mathematics self-concept amongst boys in single-sex schools than amongst girls in single-sex and coed schools. Introducing girls from single-sex classes to coed middle school mathematics classes, Durost (1996) in the US state of Maine reported that girls who have taken the class reported higher mathematics more self-confidence than their peers.

In Australia, Norton and Rennie (1998) found that boys in single-sex schools had the highest levels of mathematics confidence. The study also found that although girls in coed schools had the lowest levels of mathematics confidence, girls in single-sex schools had levels of confidence comparable to that of boys in coed schools. On the other hand, Belcher et al. (2006) found that students in single-sex classrooms had significantly higher academic self-confidence than those in coed classrooms.

In a meta-analytic critique of Mael et al. (2005) study, Signorella et al. (2013) found that controlling for pre-existing differences reduces or removes the advantages of single-sex schools and observed no significant effects on school gender composition for self-belief measures (see also, Nagengast et al. 2013). Specifically, in the domains of mathematics, there was no advantage to either single-sex or coed educational settings for mathematics self-esteem/self-concepts. In a large longitudinal study of academic self-concept, Sullivan (2009) found that, even after controlling for prior test scores, academic self-concept is highly gendered. Sullivan (2009) concluded that single-sex schooling reduced the gender gap in self-concept. On the other hand, Lee and Bryk (1986) found that boys had higher selfconcepts in mathematics and science, and girls in English.

\section{Parent-Teacher students' Relationships}

Students tend to have positive self-confidence if their parents and teachers have high expectations of them and offer them support and encouragement to accomplish their goals. Studies have shown that parental involvement in their children's education, both at home and at school, supported by cordial relationships with their teachers, increases students' and motivation to learn (Fan and Chen 2001; J. Hughes and Kwok 2007). 
Based on an empirical study, Epstein (2010) distinguished six structural themes for parental involvement, namely: parenting, communicating, volunteering, learning at home, decision making, and collaborating. This paper emphasizes parenting and learning at home. By parenting, we mean parents must guide, support, serve as a role model, have confidence, understand parenting, and be aware of the importance of school and mathematics in the child's everyday life (ibid). Learning at home means family encouragement in learning-especially mathematics, emphasizing the importance of mathematics at home, emphasizing learning as a process, supporting and helping with homework, and discussing day-to-day school activities (Epstein 2010).

Generally, girls experienced more parental involvement with their education than did boys (HooverDempsey and Sande, 1995; Jacobs and Bleeker 2004). Cultural stereotypes (e.g. that males excel in mathematics) have been shown to influence parents' perceptions of their children's abilities (Gunderson Ramirez, Levine and Beilock, 2012) and later achievement beliefs and behaviours (Bhanot 2005; Jacobs and Bleeker 2004). For example, Jacobs and Bleeker (2004) found that parents were more likely to be involved in their daughters' mathematics and science activities than in their sons' activities, and that children's interest in mathematics increased as parents became involved in their children's mathematics and science activities.

Teacher quality refers to students' self-reported attributes of their teacher with respect to how their teacher inspires, encourages, creates a positive learning atmosphere and inspiring, and varied learning situations, as well as carefully guiding students through mathematics learning processes. These learning processes stimulate students' own thought processes, and that they give students the opportunity to evaluate their own learning outcomes (Kunter et al. 2008).

Studies on the association between gender and the relationship with the teacher have varied. Several studies have all found a stronger association with females (e.g., Baker 2006), males (e.g., Furrer and Skinner 2003), and no gender impact (e.g., J. Hughes and Kwok 2007). J. Hughes and Kwok (2007) and J. N. Hughes et al. (2012) found that these variations are due in part to who reported the relationship (whether a student, teacher or observer) and whether the study assessed positive or negative dimensions of the relationship.

Given the conflicting results, Canada and Pringle (1995) suggested that the social context of the classroom influences male and female interaction with their teacher. Their study found that male and female student interaction varied as a function of the sex ratio in the classroom, although not predictably. A meta-analysis by Kelly (1988) involving 81 studies and Jones and Dindia (2004) involving 32 studies on sex differences in teacher-student interactions concluded that teachers consistently interact more with boys than with girls. The variability of the effect size across both studies indicates that some factors other than students' sex moderate the teacher-student relationship. They concluded in their analysis that teachers initiate more overall interactions, and more negative interactions but not more positive interactions with male students than with female students.

On the other hand, with regard to gender differences in junior secondary schools in Ghana, Nyala (2010) found that girls in single-sex schools received more teacher support and family encouragement in learning mathematics than did boys in coed schools and boys in single-sex schools. Boys in coed schools received more support and encouragement from their parents than did girls in coed schools. Similarly, Rennie and Parker (1997) found that girls in single-sex classes and boys in coed classes received more favorable parental support than did their peers. 
The brief literature shows variations in the conclusions and interpretations of affective structures in single-sex and coed classrooms. On students' affective dimensions, some studies favor coed schools, whereas some favor single-sex schools, and still others find no differences. In the absence of no controls for pre-existing differences, single-sex schools tended to be more favorable than coed schools. Marsh and Rowe (1996) concluded that differences are usually attributable to "the characteristics of the students who attend each type of school rather than school-type effects". (p. 148)

\section{Current Study}

The current study examined the relationship between students' "Views on Mathematics (VOM)" of themselves as learners in single-sex and coed schools in Ghana. In an earlier study, (Bofah \& Hannula, 2014, 2015b) used structural equation modeling (SEM) to determine the factor structure of Ghanaian twelfth-grade students' VOM, and a four-factor structure was deemed the best for the Ghanaian sample. The four factors were labelled self-confidence, self-concept, family encouragement, and teacher quality. The authors found empirical and theoretical support for the constructs with the reliabilities (both Cronbach's alpha $(\alpha)$ and composite reliability $(\omega)$ ) were within the acceptable thresholds; selfconcept: $\alpha=0.872,95 \%$ CI [0.864, 0.879], $\omega=0.868,95 \%$ CI [0.859, 0.877 ; teacher quality: $\alpha=0.706,95 \%$ CI [0.684, 0.727], $\omega=0.716,95 \%$ CI [0.696, 0.737]); self-confidence: $\alpha=0.690,95 \%$ CI [0.654, 0.726], $\omega=$ $0.697,95 \%$ CI [0.659, 0.736]; and family encouragement: $\alpha=.619,95 \%$ CI [0.552, 0.687], $\omega=.621,95 \%$ CI $[0.587,0.654])$.

In the present study, the following objectives formed the basis of our inquiry:

- to determine whether there are dispositional differences between students enrolled in single-sex schools versus those enrolled in coed schools with regard to the affective measures such as self-confidence, self-concept, family encouragement, and teacher quality in learning mathematics in Ghana;

- to identify gender- and school-related differences within the schools to determine whether the gender rather than the school type influences these relationships.

To achieve these objectives, we tested the following hypotheses that provide support for construct validity as a prelude to the main inquiry:

- that responses to the items would support an a priori four-factor structure, that each item would have a non-zero loading on the factor it intended to measure, and that the factors would correlate,

- the degrees of measurement invariance across the schools (invariance of factor loading, and item intercepts invariance), and that method effects would be associated with the negatively worded items.

Figure 1 depicts a schematic representation of this hypothesis. 


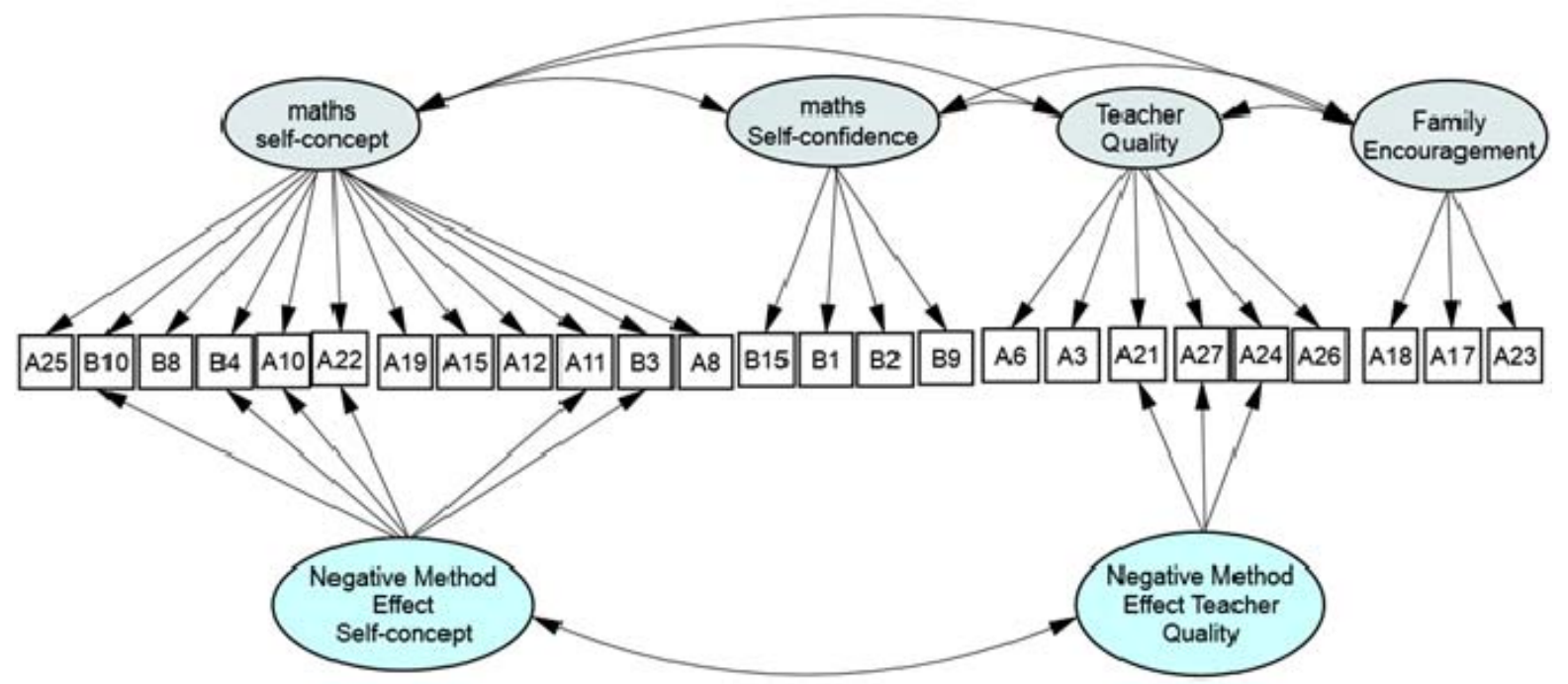

Figure 1. The hypothesized factor structure for the VOM Constructs

\section{Methodology}

\section{Participants}

Education in Ghana follows a two-tier model with three stages of compulsory schooling (Kindergarten: two years for 4-year-olds; Primary school: six years for 7 to 12-year-olds ; Junior High School : three years from age 13 to 15; and Senior Secondary Schools (upper secondary): three ${ }^{1}$ years for ages 15 to 18$)$.

In the present study, we collected data from 2034 students ( $M_{\text {Age }}=18.49, S D_{\text {Age }}=1.25 ; 58.2 \%$ girls $)$ in the 12th-grade. Nine senior high schools were selected from urban and rural schools according to the rankings by the Ghana Education Service, which are based on past student performance in matriculation exams. The Ghana Educational service rank schools according to previous matriculation examination. In the present study schools were selected from each of category of the ranking taking the school type into consideration (single-sex or coed), as such survey participants' demographics resembled overall educational population in Ghana. The survey was group administered to participants in either a classroom or school hall. The questionnaires were voluntary and students had the right to withdraw or skip any question that they did not wish to answer. The respondents were from single-sex boys (394), single-sex girls (783) and coed schools ( $\mathrm{N}=850$, boys: 456, girls: 394$)^{2}$. The schools were private, religious and public schools; some schools fell under more than one category. Students' were are enrolled in the compulsory core mathematics course, however, about $50.7 \%$ of the students also were enrolled in elective mathematics course. All respondents were pursuing General Arts (33\%), Business (19.2\%), Science $(29.1 \%)$, or Vocational Science $(18.7 \%)$ as elective major subject areas. Given the large sample size for the single-sex girls' schools, we randomly split the sample into two groups of girls from single-sex schools of the same ranking. In the present paper, the sample of girls from single-sex schools was scaled down from 783 to 509 to yield a total sample of 1753 so that potential differences between the large sample of girls in single-sex schools and their counterparts would not confound the difference between single-sex school comparisons. This huge sample differences are due to the fact that although the cohorts of single-sex schools are small, their student population is huge. Although the sample difference will not significantly affect the study due to the robust approach we decided to scale the sample. The study sample comprised 63 different student classrooms with an average class size of 32 students.

\section{Measures}

The VOM scale consists of four subscales, with twelve items on the mathematics self-confidence factor, four on the mathematics self-concept factor, six on the teacher quality factor, and three on the family encouragement factor. These four factor structures stem from earlier studies by Bofah and 
Hannula $(2014,2015 b)$ which validated the factor structure of the VOM for the Ghana sample. In that study, the original seven-factor hypothesized factor structure proposed by Hannula, (2011) did not fit the data. Further exploratory factor analysis revealed that the data best fit a four-factor structure that was further confirmed through confirmatory factor analysis. Each item was rated on a 5-point scale ranging from always (5) to never (1). Sample items for each of the variates are depicted in Table 1. For details about complete questionnaire and subsequent studies, see Bofah and Hannula (2014, 2015b) and Roesken, Hannula, and Pehkonen (2011).

\section{Statistical modeling}

Assessing Goodness-of-Fit and Estimation Models

We evaluated goodness of fit using the Root Mean Square Error of Approximation (RMSEA), the Tucker-Lewis index (TLI), the comparative fit index (CFI), as well as the chi-square test statistic (for informative purposes only because of it sensitivity to large sample size) with the following criteria as cutoffs for good fit: CFI and TLI $>.90$ (with $>.95$ being ideal), and RMSEA $<0.08$ (with $<.05$ being ideal) (Brown 2006). These model fit indices are known to be (nearly) unaffected by sample size (West, Taylor and Wu 2012). All analysis in the present study was carried out using Mplus 7.2 (Muthén \& Muthén 1998-2012). Analyses were based on the Mplus robust maximum likelihood estimator (MLR), with standard errors and a test-of-fit that are robust for non-normality and non-independence of observations (Muthén \& Muthén 1998-2012). Because popular methods to handling missing data such as mean substitution, listwise and pairwise deletion can bias the result (Allison 2001) missing data were handled with the Mplus feature of full information maximum likelihood (FIML) (Enders 2010). We also interpreted measurement invariance from a practical/approximate perspective. That is, we examined the change in CFI and RMSEA for different consecutive models. Chen (2007) propose that if the decrease in model fit for the more parsimonious model is less than or equal to .010 for CFI (see also Cheung and Rensvold 2002), or a change in RMSEA of less than .015, then there is reasonable support for the more parsimonious model.

\section{Measurement invariance (equivalence)}

Measurement invariance is testing the equivalence of the parameters (e.g., intercepts or thresholds of the factor indicators, factor loadings, and residual variances) of a measured construct in two or more groups (e.g., students' gender). It indicates that constructs are generalizable to each of the groups; that is sources of bias and error are minimal such that sex-by-school grouping differences have not differentially affect the construct of measure, and that mean differences on the underlying constructs are "quantitative in nature" (Watt et al. 2012). The process involves multiple-group confirmatory factor analysis (CFA). Measurement invariance model testing usually begins with a baseline model, often called the configural model (M2), in which all parameters in the model are freely estimated across group. The next model to test will be one that requires the factor loadings to be equal (invariance) across the groups. The model in which the factor loadings are held equal is normally called the metric invariance (M3 model). Next, we tested a model in which invariance constraints are placed on the measurement intercepts and the factor loadings. The combination of metric invariance and invariance in the measurement intercepts is known as scalar invariance (M4). Support for scalar invariance implies the population differences in the means of the measured variables is due to the means of the common factors. The last, of the invariance is strict measurement invariance, which requires that metric, scalar and item uniqueness all be invariant across groups. However, for comparisons based on latent constructs that are corrected for measurement error, comparison of latent means only requires support for scalar measurement invariance and not strict measurement invariance.

With non-scalar invariance, which indicates that factor means cannot be compared across groups, multigroup alignment optimization method, as implemented in Mplus, serves to allow the comparison of factor mean (Asparouhov and Muthén 2014; Muthén and Asparouhov 2013; Muthén 
and Muthén 2013). The multiple-group alignment optimization method allows for only approximate measurement invariance. The alignment optimization approach incorporated in the estimates, the natural assumption that the number of measurement non-invariance parameters, and the amount of measurement non-invariance are minimal (Asparouhov and Muthén 2014; Muthén and Asparouhov 2013). That is, "... a majority of the parameters are invariant and a minority of the parameters are non-invariant" (Muthén and Asparouhov 2013, p. 28). It is also based on the assumption that, whereas factor distribution can vary across groups, the measurement instrument should be similar across groups (Asparouhov and Muthén 2014). Thus, the multiple-group alignment optimization method makes the factor means and variances comparable across groups and reduces the number of significant non-invariances. The method is based on multiple pairwise comparisons and the configural model. It has the same fit as the configural model. For a detailed discussion of invariance testing and alignment estimation (including technical implementation) method, see Muthén and Asparouhov (2013); Asparouhov and Muthén (2014), and Muthén and Muthén (2013).

\section{Selection and Controlling for Grouping Bias}

One of the challenges in single-sex and coed educational research is detecting and controlling for possible selection bias associated with entry into these schools (e.g., Hayes et al. 2011; Nagengast 2013). An underlying problem associated with single-sex and coed schools research is that, is difficult to associate the outcome with the school-type because the differences may reflect the selection mechanisms associated with entry into these schools rather than the effects of the schools per se (Park et al. 2013). In an educational system such as in Ghana, wherein parent or some students' choose single-sex schools over coed schools, students in single-sex and coed schools are likely to differ in many aspects (e.g., socioeconomic background, parental support). Several critiques on the effectiveness of controlling the bias in single-sex schools can be found in the literature (e.g., Marsh 1991; Nagengast 2013). For instance, studies have found no differences in school type (single-sex or coed) when other variables are controlled (Hayes et al. 2011; Kim and Law 2012; Marsh 1989; Marsh 1991) and when students are randomly assign to schools (Pahlke 2013). However, Marsh $(1989,1991)$ argues that the possible reason for the reported differences amongst students' in the single-sex schools maybe that these schools are academically selective and being able to attract students' from affluent background (see also, Hayes et al., 2011).

Other source of selection bias have been discussed in the literature, such as national context of school sex grouping (Baker 1995), most single-sex schools either being a religious (e.g., catholic single-sex schools) or private school (F. A. Mael 1998), gendered curriculum, gendered social structure and country-specific socio-historical context (e.g., family background) on single-sex schooling (Kim and Law 2012; Signorella et al. 2013) and attitudes about school prior to entering the single-sex school (e.g., Hayes et al. 2011). Although, other studies (e.g., Hayes et al. 2011) have indicated that selection biases do not fully account for previously reported differences between students in single-sex and coed schools. The reviewed literature indicates that the three main types of selection bias that affect the outcome in single-sex and coed educational research are; student-driven selection effects, schooldriven selection and social structure selection effects (Hayes et al. 2011). These potentially confounding selection issues have not been efficiently addressed in single-sex research (e.g., F. Mael et al. 2005).

The most prominent approach used in controlling for selection bias is the propensity score method and Analysis of Covariance (ANCOVA) (Mayer et al. 2014; Nagengast et al. 2013). Nagengast et al. (2013) and colleagues have shown that the regression-based adjustment methods such as ANCOVA and propensity score approaches (e.g., linear logistic regression) yielded similar results (see also Green and Thompson 2012). As with ANCOVA design, multiple-group CFA analyses will yield comparable and even better results (Green and Thompson 2012; Mayer et al. 2014). Moreover, with multiple-group CFAs, the distributional and all assumptions required by ANCOVA can be 
circumvented (Fan 2012; Green and Thompson 2012). Thus, multiple-group CFAs can circumvents the limitations associated with the traditional ANCOVA approach.

With the propensity scores approach, large number of reliable and theoretical sound covariates needs to be collected (Kaplan 1999; Mayer et al. 2014; Nagengast 2013). Moreover, reliability of the propensity scores can be compromise if measurement errors in the covariates are not controlled. However, the significant strength of multiple-group CFA approach is the ability to model relations between latent variables, control for measurement errors, non-normality in the data, method effect associated with item phrasing, robust in relation to information lost due to the grouping, allows the inclusion of contextual effects with the appropriate controls for sampling error, and allow for the full range of invariance testing (Mayer et al. 2014) like those considered here.

In the present study, we opted for the SEM multi-group approach (multiple-group alignment optimization method) because of it superiority over the other methods. We also belief the robust methodology control other unforeseen errors allowing such comparison between the single-sex and coed schools stronger and legitimate.

\section{Analysis and Results}

An overview of the present study involves computing the reliabilities of the constructs for the four sex-by-school groups (boys in single-sex schools, girls in single-sex schools, boys and girls in co-ed schools). We posited an a priori structure and tested the structure to see if it fit our data set. Series of models incorporating method effect associated with the use of negatively worded items in a survey instrument was postulated and tested. Thereafter, analyses were conducted within the multiplegroup CFA (four sex-by-school group) alignment optimization framework using Mplus 7.2. As indicated early, this is an extension of the traditional multiple-group CFAs in circumstances whereby scalar invariance is not supported and there are more than two groups.

\section{Reliabilities}

Because the construct comes from a Western research, finding lower Composite reliability $(\omega)^{3}$ estimates would not be surprising. At least some of the reliability estimates are below an acceptable threshold, but still generally good (see Table 1 for all reliability estimates). Responses on the selfconcept variate were equally reliable for all school types. Responses for single-sex students were more reliable on the teacher quality variate than were those for coed students. The responses of boys in single-sex schools on the self-confidence variate were more reliable than those of boys in all other school types. The reliability values for coed students were below the acceptable threshold of 0.700 for teacher quality, family encouragement and mathematics self-confidence variates. Moreover, the reliability estimates for the family encouragement variate was below the acceptable threshold across all the groups, but still generally acceptable.

It is also interesting to note that the "corrected item-total correlations" (not reported) 4 tended to be higher for the six negatively worded items on self-concept variate and the three negatively worded items on teacher quality variate, and these differences appear to be greater for the responses of students in single-sex schools (high for girls single-sex schools on self-concept and for boys single-sex schools on teacher quality variate) than for the responses of students in coed schools. This suggests the possibility of a negative item effect that varies for the responses of students in single-sex and coed schools. The lower reliabilities and differences in reliability across the groups may weaken the validity of interpretations based on manifest scale scores, attenuate statistical power, and effect sizes (Marsh et al. 2013; Schmitt 1996). For this reason, it is therefore advisable to use a more robust approach to 
account for the method effect associated with the negatively worded items under consideration in this paper.

Table 1. Variates, Sample Items and Reliabilities

\begin{tabular}{lllllll}
\hline & & \multicolumn{5}{c}{ Reliability $(\omega)$} \\
\cline { 5 - 7 } Variate & \multicolumn{1}{c}{ Sample item } & $\begin{array}{c}\text { No. of } \\
\text { items }\end{array}$ & $\begin{array}{c}\text { Girls } \\
\text { single- } \\
\text { sex }\end{array}$ & $\begin{array}{c}\text { Boys } \\
\text { single- } \\
\text { sex }\end{array}$ & $\begin{array}{c}\text { Girls } \\
\text { coed }\end{array}$ & $\begin{array}{l}\text { Boys } \\
\text { coed }\end{array}$ \\
\hline SC & $\begin{array}{l}\text { I have made it well in } \\
\text { mathematics. }\end{array}$ & 12 & .892 & .871 & .855 & .862 \\
TQ & $\begin{array}{l}\text { The teacher has so far been a } \\
\text { positive example. }\end{array}$ & 6 & .736 & .756 & .676 & .612 \\
FE & $\begin{array}{l}\text { My family encourages me to } \\
\text { study mathematics. }\end{array}$ & 3 & .630 & .625 & .630 & .619 \\
SCF & $\begin{array}{l}\text { I know that I can do well in } \\
\text { Mathematics. }\end{array}$ & 4 & .671 & .758 & .695 & .641 \\
\hline
\end{tabular}

Note. $\mathrm{SC}=$ Mathematics Self-concept, $\mathrm{TQ}=$ Teacher Quality, FE = Family Encouragement, SCF = Mathematics Self-confidence

Testing of invariance across school type

As indicated earlier, measurement invariance modeling begins with the estimation of a baseline model (configural model). The present study used two a priori baseline models. The first model was what Marsh (1994) term as a typical independent cluster model in which each self-concept, self-confidence, teacher quality and family encouragement item was allowed to load on only the one factor that it is designed to measure for each grouping; the VOM factors correlated freely, and the error covariances associated with the VOM items were uncorrelated. The second model, less parsimonious than the first, differed only in that the six negatively worded items on the mathematics self-concept constructs and the three negatively items on the teacher quality constructs were set to correlate to account for the method effect associated with negatively worded items in order to improve model fit (see Figure 1). Several studies have discussed and adopted similar procedures (Distefano and Motl 2009; Horan et al. 2003; Magazine et al. 1996; Marsh 1994, 1996; Marsh et al. 2013; Schriesheim et al. 1991; Schriesheim and Hill 1981; Urbán et al. 2014).

Model 0 (M0) in Table 2 is the total model without the negatively correlated error terms (Label as Section A), and model 1(M1) is the model with the corrected error term (Label as Section B). Model 1 fits the data better than model 0 (M0) does. Results from these analyses are consistent with other studies (e.g., Distefano and Motl 2009; Horan et al. 2003; Marsh 1994, 1996; Marsh et al. 2013) reporting improved model fit after incorporating the wording effects in the model. All subsequent analysis is based on model 1 which is the baseline model for the present study depicted in figure 1. Model 1 (M1) is the hypothesized model (the baseline model) for the multi-group analysis.

Inclusion of the negative item effect improved the goodness of fit for each of the four groups (Table 2; Section B). The improvement in fit was substantial for both boys and girls in coed schools and for boys in single-sex schools (e.g., Girls in coed schools: $\mathrm{CFI}=0.894$ vs. 0.957 ; Boys in coed schools: $\mathrm{CFI}=$ 0.894 vs. 0.947; Boys in single-sex schools: $C F I=0.899$ vs. 0.952 ), but was much smaller for girls in single-sex schools (e.g., Girls in single-sex schools: $\mathrm{CFI}=0.912$ vs. 0.932 ). The combined effect of the fit indices and the "corrected item-total correlations" indicated that the method effect related to negative wording item is lower in single-sex schools, especially among girls in single-sex schools. Looking at the correlations between the negatively worded items (not reported), the "corrected item-total correlations" and the reported fit indices for groups indicated that responses to the negatively worded items needed to be included in the measurement models of the VOM to achieve adequate model fit. 
Moreover, the method effect seems to relate to both individual traits and students' associations with a particular school type rather than a methodological artifact.

Table 2. Goodness-of-Fit Summary: Four-sex-by-school groups

\begin{tabular}{|c|c|c|c|c|c|c|}
\hline Model & MLR $\chi^{2}$ & $d f$ & $\mathrm{~s}$ & RMSEA & CFI & TLI \\
\hline \multicolumn{7}{|c|}{ Section A: Models without the negatively correlated error terms } \\
\hline $\begin{array}{l}\text { Girls in single- } \\
\text { sex schools }\end{array}$ & 541.872 & 269 & 1.191 & .045 & .905 & .894 \\
\hline $\begin{array}{l}\text { Boys in single- } \\
\text { sex schools }\end{array}$ & 520.087 & 269 & 1.134 & .049 & .890 & .877 \\
\hline $\begin{array}{l}\text { Boys in coed } \\
\text { schools }\end{array}$ & 486.941 & 269 & 1.146 & .042 & .899 & .887 \\
\hline $\begin{array}{l}\text { Girls in coed } \\
\text { schools }\end{array}$ & 473.560 & 269 & 1.114 & .044 & .894 & .881 \\
\hline Total (M0) & 1045.564 & 269 & 1.189 & .041 & .912 & .902 \\
\hline \multicolumn{7}{|c|}{ Section B: Models with the corrected error term } \\
\hline $\begin{array}{l}\text { Girls in single- } \\
\text { sex schools }\end{array}$ & 438.315 & 233 & 1.187 & .042 & .928 & .908 \\
\hline $\begin{array}{l}\text { Boys in single- } \\
\text { sex schools }\end{array}$ & 346.416 & 233 & 1.126 & .035 & .950 & .936 \\
\hline $\begin{array}{l}\text { Boys in coed } \\
\text { schools }\end{array}$ & 338.177 & 233 & 1.146 & .031 & .951 & .937 \\
\hline $\begin{array}{l}\text { Girls in coed } \\
\text { schools }\end{array}$ & 313.325 & 233 & 1.108 & .030 & .958 & .946 \\
\hline Total (M1) & 573.540 & 233 & 1.187 & .029 & .962 & .951 \\
\hline \multicolumn{7}{|c|}{ Section C: Measurement invariance Models } \\
\hline M2 & 1440.823 & 932 & 1.142 & .035 & .945 & .929 \\
\hline M3 & 1527.175 & 995 & 1.567 & .035 & .943 & .931 \\
\hline M4 & 1738.984 & 1058 & 1.148 & .038 & .927 & .917 \\
\hline M5 & 2216.323 & 1249 & 1.211 & .042 & .896 & .900 \\
\hline
\end{tabular}

Note. MLR = robust maximum likelihood estimator, $d f=$ degrees of freedom, RMSEA = Root Mean Square Error of Approximation, CFI = comparative fit index, TLI = Tucker-Lewis Index, Model 0 (M0) total group model without the negatively correlated error terms, Model 1(M1) total group Model with the corrected error term, M2 = the Configural invariance Model, M3 = Metric invariance Model (M3) Model, M4 = Scalar invariance Model, M5 = Strict invariance Model.

After establishing the baseline model, multi-group-CFAs were used to investigate whether the established dimensionality and factor-loading pattern are invariance across the school type. As Table 2 indicates (Label as section C), the configural model (M2) provided a good fit to the data, indicating support for configural validity across the groups, thus paving the way for further model testing. With regard to the metric invariance (M3), the results revealed that, comparing the metric invariance to the configural invariance model, the metric invariance model fits the data set. In addition, the decrease in goodness of fit ( $\triangle \mathrm{CFI}$ and $\triangle$ RMSEA) is within acceptable cut-off limit. Metric invariance is retained, and scalar invariance (M4) is then tested. The scalar invariance model fits less better than the metric invariance model does. The metric of the latent means is based on the items with invariant intercepts, 
as such our results suggest that it is not reasonable to compare mean differences between the groups for these factors. Another approach is needed, the alignment optimization method as discuss above. We finally tested the strict measurement invariance. In addition to the normal condition for testing strict measurement invariance, the error covariance associated to negatively worded items were also restricted to be equal across the groups. The strict invariance model (M5) fit poorer. The finding is consistent with our earlier argument that substantial method effects were found to be associated with the negatively worded item. Moreover, the method effect was strongest in the single-sex schools. The finding support earlier argument that the negative item effect was substantially lower for girls in single-sex schools. The findings may be an indication of a limited individual differences, substantial error of measurement, and students' responding to the negatively worded items differently in the single-sex schools. However, one most important finding was that the structure of VOM (metric invariance) was similar across schools.

\section{Latent mean differences}

Using the fixed multi-group alignment optimization (the factor variance is fixed to zero and the factor mean is estimated) approach as discussed in section 3.3.2, the mean structure for the factor model across groups can be identified by fixing the factor mean to zero in one group and freely estimating the factor means in all other groups. In case these values are negative, we interpret them as indicating that the group being compared has lower latent mean values than the reference group and vice versa. For the logic of the mean differences, girls in single-sex schools served as the reference group. As such, the latent means for the four constructs (self-concept, self-confidence, teacher quality, and family encouragement) were fixed at zero in the sample of girls in single-sex schools. Thus, the size and direction of the differences in all four sets of latent mean differences were evaluated in relation to the constructs for the girls in single-sex schools. For pairwise comparison, the fixed alignment method served to estimate groups that are significantly different from the others. Table 3 summarizes the findings drawn from all the pairwise models, and Figure 2 provides a graphical representation of the mean differences with respect to the reference group: girls in single-sex schools. The fixed alignment optimization approach indicated that Item A27 on the teacher quality variate and items B10 and A22 on the self-concept variates proved to be noninvariant. Detail analysis indicates that, for item A27 measurements invariance hold for boys in single-sex and both sexes in coed schools but not for girls in single-sex schools. For item B10 measurement invariance hold for girls in single-sex schools and the two sexes in the coed schools. Measurement invariance holds for item A27 for girls in single-sex and boys in single-sex schools.

Table 3. Factor Mean Comparison in Descending Order: four School Groupings

\begin{tabular}{lllll}
\hline \multicolumn{1}{c}{ Ranking } & \multicolumn{1}{c}{ Group } & Estimates & SE & \multicolumn{1}{c}{ Smaller Factor Mean (5\% significant level) } \\
\hline Mathematics self-concept & & & Groups with Significantly \\
1 & $\begin{array}{l}\text { Boys in coed } \\
\text { schools }\end{array}$ & 0.041 & 0.069 & Girls in coed schools \\
2 & $\begin{array}{l}\text { Girls in single- } \\
\text { sex schools }\end{array}$ & 0.000 & - & Girls in coed schools \\
3 & $\begin{array}{l}\text { Boys in single- } \\
\text { sex schools }\end{array}$ & -0.015 & 0.074 & Girls in coed schools \\
4 & $\begin{array}{l}\text { Girls in coed } \\
\text { schools }\end{array}$ & -0.227 & 0.075 & \\
Teacher Quality & $\begin{array}{l}\text { Girls in single- } \\
\text { sex schools }\end{array}$ & 0.000 & - & $\begin{array}{l}\text { Girls in coed schools, Boys in single-sex } \\
\text { schools }\end{array}$ \\
2 & $\begin{array}{l}\text { Boys in coed } \\
\text { schools }\end{array}$ & -0.167 & 0.094 & Boys in single-sex schools \\
3 & $\begin{array}{l}\text { Girls in coed } \\
\text { schools }\end{array}$ & -0.320 & 0.098 & Boys in single-sex schools
\end{tabular}




\begin{tabular}{|c|c|c|c|c|}
\hline 4 & $\begin{array}{l}\text { Boys in single- } \\
\text { sex schools }\end{array}$ & -0.608 & 0.112 & \\
\hline \multicolumn{5}{|c|}{ Family Encouragement } \\
\hline 1 & $\begin{array}{l}\text { Girls in single- } \\
\text { sex schools }\end{array}$ & 0.000 & - & $\begin{array}{l}\text { Girls in coed schools, Boys in single-sex } \\
\text { schools, Boys in coed schools }\end{array}$ \\
\hline 2 & $\begin{array}{l}\text { Girls in coed } \\
\text { schools }\end{array}$ & -0.375 & 0.114 & \\
\hline 3 & $\begin{array}{l}\text { Boys in single- } \\
\text { sex schools }\end{array}$ & -0.390 & 0.130 & \\
\hline 4 & $\begin{array}{l}\text { Boys in coed } \\
\text { schools }\end{array}$ & -0.507 & 0.120 & \\
\hline \multicolumn{5}{|c|}{ Mathematics self-confidence } \\
\hline 1 & $\begin{array}{l}\text { Girls in single- } \\
\text { sex schools }\end{array}$ & 0.000 & - & Boys in coed schools, Girls in coed schools, \\
\hline 2 & $\begin{array}{l}\text { Boys in single- } \\
\text { sex schools }\end{array}$ & -0.278 & 0.127 & \\
\hline 3 & $\begin{array}{l}\text { Girls in coed } \\
\text { schools }\end{array}$ & -0.381 & 0.125 & \\
\hline 4 & $\begin{array}{l}\text { Boys in coed } \\
\text { schools }\end{array}$ & -0.425 & 0.124 & \\
\hline
\end{tabular}

Note. Reference group is girls in single-sex schools. For convenience seek, the factor means are ordered from high to low and groups that have factor means significantly different on the $5 \%$ level are shown. $S E=$ standard errors.

Self-Concept: a sex-by-school-type comparison indicated that, the only statistically significant difference was between the two sexes in the coed schools. Girls in coed schools ranked the lowest, and boys in coed schools ranked the highest on mathematics self-concept. Boys in single-sex schools were not statistically different from girls in single-sex schools.

Teacher quality: Girls in single-sex schools had statistically significant higher teacher quality scores than did boys in single-sex schools and girls in coed schools. In addition, the two sexes in the coed schools reported statistically significant higher teacher quality than did boys in single-sex schools. The rankings indicated that boys in single-sex schools reported the lowest teacher quality, with girls in single-sex schools reporting the highest teacher quality.

Family encouragement: for this variate, girls in single-sex schools reported receiving statistically significant higher family encouragement than did boys in single-sex schools, boys in coed schools, and girls in coed schools. The rankings indicated that students in single-sex schools received more parental encouragement with their education than students in coed schools did. Boys in coed schools reported receiving the least family encouragement.

Self-confidence: Girls in single-sex schools have statistically significant higher mathematics selfconfidence than did boys or girls in coed schools. Girls in single-sex schools reported the highest mathematics self-confidence, whereas girls in coed schools reported the lowest mathematics selfconfidence. 


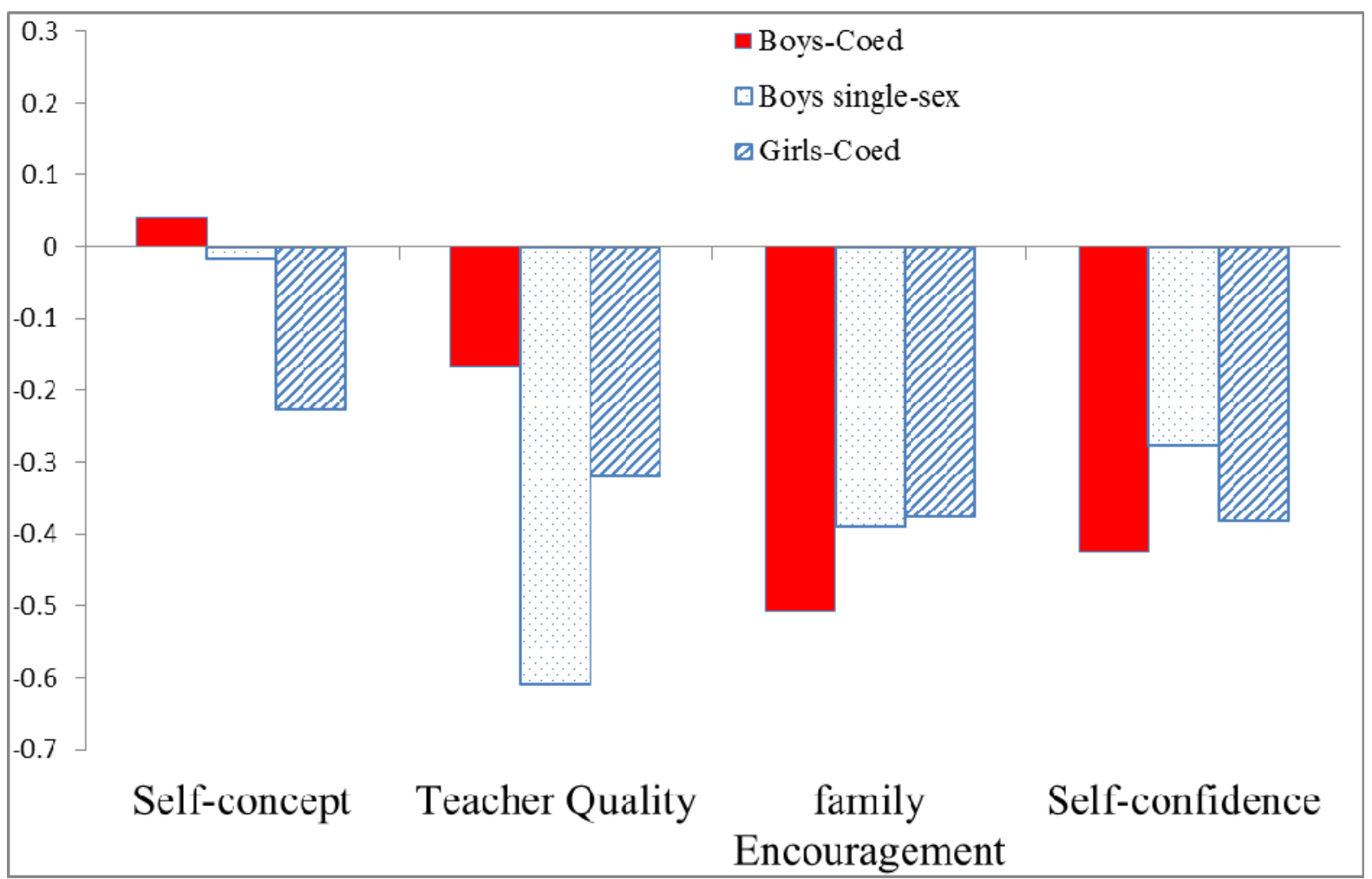

Figure 2. Latent mean differences across samples: School-type $x$ Sex. Note: the reference group is girls in single-sex schools.

Correlational Analyses

Comparison indicated a statistically significant relation (see Table 4) between all the variates for both boys and girls in coed schools and girls in single-sex schools. For girls in coed schools, the statistically significant relationship was between .182-.564; for boys in coed schools, the relations were between .269-.677, and for girls in single-sex schools, the relationship was between .176-.437. For boys in singlesex schools, correlations were between .223-.720. An interesting pattern emerged with respect to the most salient relationship. The most salient relationship within single-sex schools was between students' self-concept and teacher quality (boys in single-sex schools: $r=.720$; girls in single-sex schools: $r=.437$ ), whilst the most salient relationships in the coed schools were between self-concept and selfconfidence (boys in coed schools: $r=.677$; girls in coed schools: $r=.564$ ). In all, the only nonsignificant relationship amongst boys in single-sex schools was between family encouragement and student selfconfidence.

The correlational analysis indicated that within the single-sex schools, the teacher is statistically significantly related to students' self-concept, especially for boys' single-sex schools. Amongst boys in coed schools, family encouragement proved to be highly statistically significantly related to students' self-belief, whereas in girls single-sex schools family encouragement is statistically significantly related to students' self-confidence and the teacher quality is statistically significantly related to students' self-concept. All school types showed a strong relationship between students' self-concept and self-confidence.

Table 4. Correlational Analysis Summary of the VOM constructs

\begin{tabular}{lllll}
\hline School type/Variates & $\begin{array}{l}\text { Mathematics } \\
\text { self-concept }\end{array}$ & $\begin{array}{l}\text { Teacher } \\
\text { quality }\end{array}$ & $\begin{array}{l}\text { Family } \\
\text { encouragement }\end{array}$ & $\begin{array}{l}\text { Mathematics } \\
\text { self-confidence }\end{array}$ \\
\hline Girls in single-sex schools & & & & \\
Mathematics self-concept & 1 & & & \\
Teacher quality & $.437^{* * *}$ & 1 &
\end{tabular}




\begin{tabular}{|c|c|c|c|c|}
\hline Family encouragement & $.279^{* *}$ & $.186^{* *}$ & 1 & \\
\hline Mathematics self-confidence & $.358^{* * *}$ & $.176^{* *}$ & $.258^{* *}$ & 1 \\
\hline \multicolumn{5}{|l|}{ Boys in single-sex schools } \\
\hline Mathematics self-concept & 1 & & & \\
\hline Teacher quality & $.720^{* * *}$ & 1 & & \\
\hline Family encouragement & $.290^{* * *}$ & $.258^{* *}$ & 1 & \\
\hline Mathematics self-confidence & $.469^{* * *}$ & $.392^{* *}$ & .223 & 1 \\
\hline \multicolumn{5}{|l|}{ Boys in coed schools } \\
\hline Mathematics self-concept & 1 & & & \\
\hline Teacher quality & $.331^{* * *}$ & 1 & & \\
\hline Family encouragement & $.409^{* * *}$ & $.269^{* *}$ & 1 & \\
\hline Mathematics self-confidence & $.677^{* * *}$ & $.298^{* *}$ & $.325^{* *}$ & 1 \\
\hline \multicolumn{5}{|l|}{ Girls in coed schools } \\
\hline Mathematics self-concept & 1 & & & \\
\hline Teacher quality & $.336^{* * *}$ & 1 & & \\
\hline Family encouragement & $.182^{*}$ & $.280 * *$ & 1 & \\
\hline Mathematics self-confidence & $.564^{* * *}$ & $.287^{* *}$ & $.434^{* *}$ & 1 \\
\hline
\end{tabular}

${ }^{* * *} p<0.001,{ }^{* *} p<0.01,{ }^{*} p<0.05$

\section{Discussion and Conclusion}

Our study is a substantive-methodological synergy (Marsh and Hau 2007). It is of practical importance for research, theory and practice in single-sex-, coed-schools, and mathematics-related affect. We applied structural equation modeling to examine the factorial structure of students' views on mathematics as well as examining the psychometric properties of the construct. Further, the methodological focus address an important problem associated with negatively worded items in selfbelief instruments. Ironically, the current study is also unique in the sense that it formally evaluated measurement invariance across the four school-types. After establishing a substantive multidimensional VOM measure, difference amongst the school-types on the VOM constructs were investigated across the four groups. In the following, we summarize and discuss results in more detail.

\section{Validity and Reliability}

In line with our a priori prediction, there was substantial evidence of method effect with the negatively worded items. Without taking into account the method effect associated with the negatively worded items, the CFAs did not meaningfully fit the data. Controlling for the method effect resulted in substantive improvement and empirical support for the four a priori VOM constructs. The current study, as well as Schmitt and Allik (2005), find support for the effect of negatively worded items to correlates within different learning environments. Moreover, the current study as well as others in literature support the evidence that without accounting for effect of the negatively worded items can impair the reliability and validity of the measures (Magazine, Williams, \& Williams, 1996; Schriesheim, Eisenbach, \& Hill, 1991; Schriesheim \& Hill, 1981; Urbán, Szigeti, Kökönyei, \& Demetrovics, 2014).

Finally, it was notable that school-type whereby the method effect tend to very substantial reported lower math self-confidence, family encouragement and teacher quality. Thus, students' with high mathematics self-confidence, high family encouragement and higher teacher quality are more likely to report their self-belief more accurately and not sensitive to item phrasing. Thus, the present study indicates that girls in single-sex schools are more likely to report their self-belief more accurately and are less sensitive to item phrasing. We conclude that, responses to the negatively worded items relate 
to both individual traits and students' association with a particular school type rather than a methodological artefact.

The latent mean is normally tested with the assumption of scalar measurement invariance (equal factor loading and item intercept). This test was very important since it has not been performed for the students' school-type with the VOM data. Although, there was support for the configural and the metric invariance models across the groups, there was no support for scalar invariance, which necessitated the use of the alignment optimization approach. Two items found to be approximately noinvariance were found within the self-concept (item A22, and B10) construct and one item on the teacher quality (item A27) construct. These items were all negatively worded. The factor loading had good support despite substantive differences in reliability. This shows that the participants responded to the negatively worded items differently in each school-type. It also indicates a lack of support for strict measurement invariance.

\section{Differences on the VOM Constructs}

The present study aimed to examine whether students views for learning mathematics differ in single-sex schools and those in coed schools. The results indicate that student views for learning mathematics within certain learning environments (e.g. single-sex and coed schools) are never identical. Summary findings indicate that students tend to have positive self-confidence and selfconcepts if their parents and teachers offer support and encouragement. The present study clearly shows that students' perceptions of their own mathematics beliefs are both a function of school type (coed, single-sex) and gender. A grouping summary indicated that students' in single-sex schools show a pattern different from that of students' in coed schools. Moreover, our analyses show that single-sex and coed schools are causally linked with students' views on mathematics. Boys in coed schools were statistically significantly different from girls in single-sex schools in mathematics selfconfidence and family encouragement.

Moreover, boys in coed-schools were statistically significantly different from boys in single-sex schools and girls in coed schools on teacher quality and mathematics self-concept respectively. Boys in single-sex schools differed statistically significantly from girls in single-sex schools on the family encouragement variate and differed statistically significantly from both girls in single-sex school and boys in coed schools on the teacher quality variate. Girls in coed schools differed statistically significantly from boys in coed schools, girls in single-sex schools and boys in single-sex schools on the mathematics self-concept variate, as well as from girls in single-sex schools on teacher quality, mathematics self-confidence variate and family encouragement variates.

The results of statistically significant findings on mathematics self-concepts amongst boys in coed school confirm earlier findings that indicate higher self-concepts among boys (Else-Quest et al. 2010; Marsh et al. 2013; McGraw et al. 2006; Sullivan 2009) and contradict studies that show no effect (e.g., Nagengast et al. 2013). Findings that indicates no statistically significant difference in school type attest to other studies (Brown \& Ronau 2012; Nagengast et al. 2013; Signorella et al. 2013), but contradict findings that indicate higher mathematics self-concepts among girls in single-sex schools (Belcher et al. 2006; Marsh et al. 2013; Riordan 1990) and for boys in single-sex schools (Githua and Mwangi 2003; Sullivan 2009).

Findings of reported high mathematics self-confidence amongst girls in single-sex schools confirm earlier studies (Belcher et al. 2006; Eshun 2004; Mallam 1993; Nyala 2010; Rowe 1988). These findings also support those other studies that have found no difference in boys and girls in single-sex schools (Brown and Ronau 2012; Signorella et al. 2013) but contradict studies showing higher self-confidence amongst boys in single-sex schools (Githua and Mwangi 2003; Norton and Rennie 1998). The literature supports comparable levels of mathematics confidence among both sexes in coed schools 
(e.g., Norton and Rennie 1998) but does not support the findings of Asante (2012) and McGraw et al. (2006).

Commenting on the statistically significantly higher mathematics self-confidence reported among single-sex schools, particularly among girl single-sex schools, one possible explanation may be that students in coed schools have much more freedom than students in single-sex schools and that this lack of freedom compels students in single-sex schools to focus more on academic work than do those in coed schools boosting their confidence level. Also, some of the schools from which the girls in single-sex schools were sampled are among the "high value" schools in Ghana, and the societal perception of an "excellent" student as one who attends one of those schools may have contributed to the students' high self-confidence even though, boys in general exhibits higher mathematics affective dispositions than girls (e.g., McGraw et al. 2006). On the math confidence variate, this study confirms previous studies of some schools in Ghana (Eshun 2004; Nyala 2010).

The lack of statistically significant difference in mathematics self-concepts between single-sex schools, together with the statistically significantly higher mathematics self-confidence amongst girls in singlesex and coed schools could be explained by well-established frames of reference effect based on selfbelief theory (e.g., Bong and Skaalvik 2003; Marsh et al. 2013). Self-belief theory also explains the statistically significant difference in mathematics self-concepts between boys in coed and girls in coed schools. The frame of reference effect (e.g., Bong and Skaalvik 2003) is known to strongly influence self-belief (e.g. self-concept) so that comparisons of schools are unlikely to revealed individual student self-beliefs. For instance, the frame of reference of a student studying in a single-sex school will be specific to each gender in the same class. Thus, girls may rank their mathematics self-concept lower if their comparison group is boys, but higher if their comparison group is other girls.

If we use gender stereotype threat theory (Steele 1997), which states that gender stereotype roles (e.g. mathematics is a male subject) can affect a member of a group targeted by and can lead to that group reporting a lower self-concept or lower self-confidence when reporting their mathematics self-beliefs. In most instances, the gender stereotype roles trigger what Steele (1997) terms "inferiority anxiety". For instance, once the rumor that mathematics is a male subject becomes active in the classroom, it induces "internalized inferiority anxiety" that, in turn, leads to a lower sense of the self (selfconfidence/self-concept) , lower motivation and lower achievement [ibid.].

The lower reported statistically significant self-concept and self-confidence of girls in coed schools and their general rankings not only support the gender stereotype threat theory, but also the same theory is supported when viewed at the school level. Girls in single-sex schools reported mathematics selfconfidence which was higher than that of girls in coed schools. Moreover, if you compare girls in single-sex schools and boys in single-sex schools on the students' self-confidence and self-concept based on the rankings, the "inferiority anxiety" or the gender stereotype threat is reverse in favor of girls in single-sex schools. This indicates that in the Ghanaian school settings, the "inferiority anxiety" or the gender stereotype threat is lower for girls in single-sex schools than for boys in single-sex schools. Summary findings indicates that, sex role identity played a significant role in developing one's mathematics self-concept, whilst school-type rather than individual traits played a significant role in the development of mathematics self-confidence. This study concludes that self-concept is gender specific.

With regard to the teacher quality variate, the findings showed differences in single-sex schools, and the rankings show no clear influence of school type or student gender. Non-significant difference existed for the teacher quality variate between girls and boys in coed schools, suggesting that gender do not influence teacher-students interaction in the coed schools. The lack of statistically 
significantly difference in teacher quality between boys and girls in coed schools contradicts the findings of other studies (e.g., J. Hughes \& Kwok, 2007). Moreover, the high reported statistically significant teacher quality amongst girls in single-sex schools confirms other studies (e.g., Rennie and Parker 1997). Other findings indicated that the differences in sex and school type in teacherstudent interactions in Ghana were more complex. Our findings were consistent with the results of other studies (Baker 2006; J. Hughes \& Kwok 2007; J. N. Hughes et al. 2012). Because of the complexity of the relations in this study, one could argue, as in Canada and Pringles (1995), that the social context inside and outside the classroom influences the students' interactions with the teacher. Boys and girls are treated differently, but school-type and sex may be only two of several factors that define differential treatments. These findings are similar to that of a meta-analytic study by Jones and Dindia (2004), which found a similar complex structure.

Moreover, the complexity of the student-teacher relationship is based on the fact that, at this level of students' education, interaction with teachers is multi-dimensional due to the subject-teacher approach at this level, and in some cases, students move between classrooms for other lessons. Contact between teachers then becomes limited, and distrust between teachers and students can grow if the students feel that they are not moving towards similar goals as their teachers (Mihalas et al. 2009). A look at the outcome on the teacher quality variate indicates that single-sex schools are very demanding in teacher quality, especially of boys in single-sex schools.

Girls in singles-sex and girls in coed schools reported higher family encouragement than do boys in single-sex and boys in coed schools respectively. These findings support others in the literature (Hoover-Dempsey and Sander 1995; Jacobs and Bleeker 2004; Nyala 2010). The lack of statistically significant difference in family encouragement between boys and girls in coed schools contradicts the findings of other studies (Gunderson et al. 2012; Jacobs and Bleeker 2004). Girls in single-sex schools reported both higher teacher quality and family encouragement that together with the correlational analysis (Table 4) indicated a similar pattern of support from both teachers and parents amongst girls in single-sex schools. One possible explanation may be that, parents and teachers' perceptions that girls in single-sex schools needed more help in this area. This interpretation supports others' findings (Hoover-Dempsey and Sander 1995; Jacobs and Bleeker 2004) that parents and teachers are more likely to become involved in activities with their children/students if they believe that their children/students need help. This unsolicited support that girls received may indicate that they actually need help and may negatively affect their self-perceptions (Bhanot 2005; Gunderson et al. 2012). The finding also endorses the parental stereotype that mathematics is difficult for girls (e.g., Gunderson et al. 2012). A close look at the rankings also shows a clear institutional gender bias on the part of teachers and parents in support of girls in single-sex schools and a gender bias in the coed schools, where boys receive the least family and teacher support.

Although we found that girls in single sex and coed schools are the main recipients of total support (e.g. teacher and parents), this finding should not be exaggerated. Other factors, such as social factors outside the classroom, may have influenced the outcome of this study. The interactive model of Deaux and Major (1987) could serve to explore the richness and diversity of the social interactive process between teachers, parents and the students in classrooms in Ghana (Jones \& Dindia, 2004). The Deaux and Major's interactive approach model of sex and gender differences acknowledges the importance of cognitive and cultural influences on sex roles suggesting that more immediate factors, such as expectations and situational pressures, as well as social and cultural patterns of discrimination, shape school and gender- related behavior. In fact, these factors may be responsible for the diverse research findings. At the center of this approach are the perceiver (the teacher, the parent) and the receiver (the student), who enters the school with gender-related schemas. Once a gender schema is activated in a perceiver, this schema as well as the perceiver's goals for the interaction will channel the perceiver's behavior toward the target (student). The relationship or 
interaction between these variates is viewed as process-oriented and ongoing, and occurs in an environment that makes school and sex-related issues more or less salient (Jones and Dindia 2004).

\section{Limitations and recommendation}

The present study has many limitations that make generalizations beyond this homogeneous sample difficult. First, we could not randomly assign the participants to single-sex or coed schools. Enrollment in single-sex schools are voluntary in Ghana, as such a truly randomized designs are impossible to implement in the current study. Nonetheless, the weakness of non-random assignment have been addressed via the methodological procedures applied in this study. Second, we could not control for students' prior achievement, socio-economic status, ethnic background, homogeneity in the school types and family background. We did not measure these variables, so their impacts are unknown; as other studies (e.g., Marsh, 1989; Nagengast et al., 2013) have shown they may exert a greater influence on the variates.

We also could not determine whether these affective construct are formed early in the students' school cycle and whether they remain constant or diminish throughout secondary schooling. A longitudinal study will be needed to solve this paradox. Another limitation of this study was that all the data were self-reports and thus subject to social desirability biases.

In Ghana, some single-sex and coed schools tend to be highly selective with respect to students and teachers. As such, it is impossible to rule out other factors accounting for group differences other than group composition between students. The selection bias occurs prior to enrolment in those schools. Moreover, the main reason behind the selection bias is prior academic achievement and, in some cases, "protocol admission" and "whom you know" (Agyeman 2013). However, differences in cultural values and norms may limit the generalizability of these findings to Ghana. While some consider the provision of single-sex schools over coed schools as a means of addressing issues of gender equity, particularly for girls (e.g., Pollard 1999), others have injected a note of caution, stating that it is not the single-sex context per se which is significant but factors such as student ability, class size, socioeconomic status, school type (private vs. public), selection bias, school characteristics (e.g., size, organizational structures), effective teaching, committed and well-trained teachers, and a strong academic focus are very important (Jackson and Smith 2000; Marsh and Rowe 1996; Nagengast et al. 2013).

The empirical findings from this study of single-sex and coed schools will assist teachers and policymakers in providing both boys and girls the best instruction in mathematics teaching and learning. If subsequent research supports the positive findings of this study and concludes that these findings are intrinsic to single-sex or coed schooling, then policy makers should find ways to preserve existing single-sex schools and, if possible, encourage their development in areas where the option does not currently exist.

Clearly, the VOM constructs studied have proved to be very important for students' adjustment to school and life in general. These findings have uncovered a fascinating relationship between these constructs, which are known to affect students' achievement. Policies that will boost math confidence amongst girls in coed schools should be instituted to help bridge the gap. Nevertheless, the strength of this study could have been stronger had controls for background variables such as achievement, students attitudes towards mathematics, socioeconomic background, and parental involvement prior to secondary school entry (junior secondary school) been available.

Summary recommendations based on the correlation findings and the mean comparison revealed strong support for single-sex schools. The present study indicates that parents should enroll their 
children in either single-sex or in coed schools with considerable support. With that in mind, we also suggest that schools should initiate policies to increase the effectiveness of parental involvement by implementing interventions that target parents.

\section{References}

Agyeman, N. K. (2013). No more protocol admissions- minister. Graphic Online. Retrieved August 22, 2013, from http://graphic.com.gh/news/general-news/7585-no-more-protocol-admissions-education-minister.html

Allison, P. D. (2001). Missing data (Sage University Papers Series on Quantitative Applications in the Social Sciences, vol 136). Thousand Oaks, CA: Sage.

Asante, K. O. (2012). Secondary students' attitudes towards mathematics. Ife Psychologia, 20(1), 121-133.

Asparouhov, T., \& Muthén, B. (2014). Multiple-group factor analysis alignment. Structural Equation Modeling, 21(4), 495-508. doi:10.1080/10705511.2014.919210.

Baker, D. P. (1995). The effects of sex-grouped schooling on achievement: The role of national context. Comparative Education Review, 39(4), 468-482.

Baker, J. A. (2006). Contributions of teacher-child relationships to positive school adjustment during elementary school. Journal of School Psychology, 44(3), 211-229.

Belcher, C., Frey, A., \& Yankeelov, P. (2006). The effects of single-sex classrooms on classroom environment, self-esteem, and standardized test scores. School Social Work Journal, 31(1), 61-75.

Bhanot, R. (2005). Do parents' academic gender stereotypes influence whether they intrude on their children's homework? Sex Roles, 52(9), 597-607.

Bigler, R. S., \& Signorella, M. L. (2011). Single-sex education: New perspectives and evidence on a continuing controversy. Sex Roles, 65(9-10), 659-669.

Bong, M., \& Skaalvik, E. M. (2003). Academic self-concept and self-efficacy: How different are they really? Educational Psychology Review, 15(1), 1-40.

Brown, S. L., \& Ronau, R. R. (2012). Students' perceptions of single-gender science and mathematics classroom experiences. School Science and Mathematics, 112(2), 66-87.

Brown, T. A. (2006). Confirmatory factor analysis for applied research. New York: Guilford Press.

Canada, K., \& Pringle, R. (1995). The role of gender in college classroom interactions: A social context approach. Sociology of Education, 68(3), 161-186.

Chen, F. F. (2007). Sensitivity of goodness of fit indexes to lack of measurement invariance. Structural Equation Modeling, 14(3), 464-504.

Cheung, G. W., \& Rensvold, R. B. (2002). Evaluating goodness-of-fit indexes for testing measurement invariance. Structural Equation Modeling, 9(2), 233-255.

Deaux, K., \& Major, B. (1987). Putting gender into context: An interactive model of gender-related behavior. Psychological Review, 94(3), 369.

Distefano, C., \& Motl, R. W. (2009). Methodological artifact or substance? Examinations of wording effects associated with negatively worded items. In T. Teo, \& M. S. Khine (Eds.), Structural equation modeling in educational research: Concepts and applications (pp. 59-77). Boston: Sense Publishers.

Durost, R. A. (1996). Single sex math classes: What and for whom? One school's experiences. NASSP Bulletin, 80(577), 27-31.

Else-Quest, N. M., Hyde, J. S., \& Linn, M. C. (2010). Cross-national patterns of gender differences in mathematics: A metaanalysis. Psychological Bulletin, 136(1), 103.

Enders, C.K. (2010). Applied missing data analysis. New York: Guilford Press.

Epstein, J. L. (2010). School/ family/ community partnerships: Caring for the children we share. Phi Delta Kappan, 92(3), 81-96.

Eshun, B. A. (2004). Sex-differences in attitude of students towards mathematics in secondary schools. Mathematics Connection, 4, 1-13.

Fan, W. (2012). Robust means modeling: An alternative for hypothesis testing of independent means under variance heterogeneity and nonnormality. Journal of Educational and Behavioral Statistics, 37(1), 137.

Fan, X., \& Chen, M. (2001). Parental involvement and students' academic achievement: A meta-analysis. Educational Psychology Review, 13(1), 1-22.

Furrer, C., \& Skinner, E. (2003). Sense of relatedness as a factor in children's academic engagement and performance. Journal of Educational Psychology, 95(1), 148.

Githua, B. N., \& Mwangi, J. G. (2003). Students' mathematics self-concept and motivation to learn mathematics: Relationship and gender differences among Kenya's secondary-school students in Nairobi and rift valley provinces. International Journal of Educational Development, 23(5), 487-499.

Green, S. B., \& Thompson, M. S. (2012). A flexible structural equation modeling approach for analyzing means. In R. H. Hoyle (Ed.), Handbook of structural equation modeling (pp. 392-416). New York: The Guilford Press.

Gunderson, E. A., Ramirez, G., Levine, S. C., \& Beilock, S. L. (2012). The role of parents and teachers in the development of gender-related math attitudes. Sex Roles, 66(3-4), 153-166.

Hayes, A. R., Pahlke, E. E., \& Bigler, R. S. (2011). The efficacy of single-sex education: Testing for selection and peer quality effects. Sex Roles, 65(9-10), 693-703.

Hayes, A. R., Pahlke, E. E., \& Bigler, R. S. (2011). The efficacy of single-sex education: Testing for selection and peer quality effects. Sex Roles, 65(9-10), 693-703. 
Hoover-Dempsey, K., \& Sander, H. (1995). Parental involvement in children's education: Why does it make a difference? The Teachers College Record, 97(2), 310-331.

Horan, P. M., DiStefano, C., \& Motl, R. W. (2003). Wording effects in self-esteem scales: Methodological artifact or response style? Structural Equation Modeling, 10(3), 435-455

Hughes, J. N., Wu, J., Kwok, O., Villarreal, V., \& Johnson, A. Y. (2012). Indirect effects of child reports of teacher-student relationship on achievement. Journal of Educational Psychology, 104(2), 350-365.

Hughes, J., \& Kwok, O. (2007). Influence of student-teacher and parent-teacher relationships on lower achieving readers' engagement and achievement in the primary grades. Journal of Educational Psychology, 99(1), 39-51.

Jackson, C., \& Smith, I. D. (2000). Poles apart? An exploration of single-sex and mixed-sex educational environments in Australia and England. Educational Studies, 26(4), 409-422.

Jacobs, J. E., \& Bleeker, M. M. (2004). Girls' and boys' developing interests in math and science: Do parents matter? New Directions for Child and Adolescent Development, 2004(106), 5-21.

Jones, S. M., \& Dindia, K. (2004). A meta-analytic perspective on sex equity in the classroom. Review of Educational Research, 74(4), 443-471.

Kaplan, D. (1999). An extension of the propensity score adjustment method for the analysis of group differences in MIMIC models. Multivariate Behavioral Research, 34(4), 467.

Kelly, A. (1988). Gender differences in teacher-pupil interactions: A meta-analytic review. Research in Education, 39(1), 1-23.

Kim, D. H., \& Law, H. (2012). Gender gap in maths test scores in South Korea and Hong Kong: Role of family background and single-sex schooling. International Journal of Educational Development, 32(1), 92-103.

Kim, D. H., \& Law, H. (2012). Gender gap in maths test scores in South Korea and Hong Kong: Role of family background and single-sex schooling. International Journal of Educational Development, 32(1), 92-103.

Kunter, M., Tsai, Y., Klusmann, U., Brunner, M., Krauss, S., \& Baumert, J. (2008). Students' and mathematics teachers' perceptions of teacher enthusiasm and instruction. Learning and Instruction, 18(5), 468-482.

Lee, V. E., \& Bryk, A. S. (1986). Effects of single-sex secondary schools on student achievement and attitudes. Journal of Educational Psychology, 78(5), 381.

Mael, F. A. (1998). Single-sex and coeducational schooling: Relationships to socioemotional and academic development. Review of Educational Research, 68(2), 101-129.

Mael, F., Alonso, A., Gibson, D., Rogers, K., Smith, M. \& American Institutes for Research (2005). Single-sex versus coeducational schooling: A systematic review. doc\# 2005-01. US Department of Education.

Magazine, S. L., Williams, L. J., \& Williams, M. L. (1996). A confirmatory factor analysis examination of reverse coding effects in MEYER and ALLEN'S affective and continuance commitment scales. Educational and Psychological Measurement, 56(2), 241-250.

Mallam, W. A. (1993). Impact of school-type and sex of the teacher on female students' attitudes toward mathematics in Nigerian secondary schools. Educational Studies in Mathematics, 24(2), 223-229.

Marsh, H. W. (1989). Effects of attending single-sex and coeducational high schools on achievement, attitudes, behaviors, and sex differences. Journal of Educational Psychology, 81(1), 70.

Marsh, H. W. (1989). Effects of attending single-sex and coeducational high schools on achievement, attitudes, behaviors, and sex differences. Journal of Educational Psychology, 81(1), 70.

Marsh, H. W. (1991). Public, catholic single-sex, and catholic coeducational high schools: Their effects on achievement, affect, and behaviors. American Journal of Education, 99(3), 320-356.

Marsh, H. W. (1994). Using the national longitudinal study of 1988 to evaluate theoretical models of self-concept: The selfdescription questionnaire. Journal of Educational Psychology, 86(3), 439.

Marsh, H. W. (1996). Positive and negative global self-esteem: A substantively meaningful distinction or artifactors? Journal of personality and social psychology, 70(4), 810. doi:10.1037/0022-3514.70.4.810.

Marsh, H. W., Abduljabbar, A. S., Abu-Hilal, M. M., Morin, A. J., Abdelfattah, F., Leung, K. C., . . Parker, P. (2013). Factorial, convergent, and discriminant validity of TIMSS math and science motivation measures: A comparison of Arab and Anglo-Saxon countries. Journal of Educational Psychology, 105(1), 108-128. Doi: 10.1037/a0029907.

Marsh, H. W., \& Hau, K.-T. (2007). Applications of latent-variable models in educational psychology: The need for methodological-substantive synergies. Contemporary Educational Psychology, 32, 151-170. doi:10.1016/j.cedpsych.2006.10.008.

Marsh, H. W., \& Rowe, K. J. (1996). The effects of single-sex and mixed-sex mathematics classes within a coeducational school: A reanalysis and comment. Australian Journal of Education, 40(2), 147-161.

Mayer A, Nagengast B, Fletcher J, \& Steyer R. (2014). Analyzing average and conditional effects with multigroup multilevel structural equation models. Frontiers in Psychology, doi:10.3389/fpsyg.2014.00304

McGraw, R., Lubienski, S. T., \& Strutchens, M. E. (2006). A closer look at gender in NAEP mathematics achievement and affect data: Intersections with achievement, race/ethnicity, and socioeconomic status. Journal for Research in Mathematics Education, 37(2), 129-150.

Mihalas, S., Morse, W. C., Allsopp, D. H., \& McHatton, P. A. (2009). Cultivating caring relationships between teachers and secondary students with emotional and behavioral disorders implications for research and practice. Remedial and Special Education, 30(2), 108-125.

Muthén, B., \& Asparouhov, T. (2013). New methods for the study of measurement invariance with many groups. Alignment: A new multiple-group CFA method. Retrieved from http://www.statmodel.com/Alignment.shtml.

Muthén, L. K., \& Muthén, B. O. (1998-2012). Mplus user's guide (7th Ed.). Los Angeles, CA: Muthén \& Muthén. 
Muthén, L., \& Muthén, B. (2013). Mplus user guide: Mplus language addendum 7.1. Los Angeles, CA: Muthén \& Muthén.

Nagengast, B., Marsh, H. W., \& Hau, K. T. (2013). Effects of single-sex schooling in the final years of high school: A comparison of analysis of covariance and propensity score matching. Sex roles, 69(7-8), 404-422.

Norton, S. J., \& Rennie, L. J. (1998). Students' attitudes towards mathematics in single-sex and coeducational schools. Mathematics Education Research Journal, 10(1), 16-36.

Nyala, I. J. (2010). Sex-differences in attitudes, achievement in mathematics and intended participation in elective mathematics of junior secondary school students. (Unpublished Master's Thesis). University of Cape Coast, Ghana, Cape Coast.

Pahlke, E. (2013). The effects of single-sex compared with coeducational schooling on mathematics and science achievement: Data from Korea. Journal of Educational Psychology, 105(2), 444-452.

Park, H., Behrman, J. R., \& Choi, J. (2013). Causal effects of single-sex schools on college entrance exams and college attendance: Random assignment in Seoul high schools. Demography, 50(2), 447-469.

Park, H., Behrman, J. R., \& Choi, J. (2013). Causal effects of single-sex schools on college entrance exams and college attendance: Random assignment in Seoul high schools. Demography, 50(2), 447-469.

Parker, P. D., Marsh, H. W., Ciarrochi, J., Marshall, S., \& Abduljabbar, A. S. (2014). Juxtaposing math self-efficacy and selfconcept as predictors of long-term achievement outcomes. Educational Psychology, 34(1), 29-48. doi:10.1080/01443410.2013.797339

Patterson, M. M., \& Pahlke, E. (2011). Student characteristics associated with girls' success in a single-sex school. Sex Roles, 65(910), 737-750.

Pollard, D. S. (1999) Single sex education. WEEA Digest. Newton, MA: Education Development Centre.

Purkey, W. W. (1970). Self-concept and school achievement. Oxford, England: Prentice-Hall.

Raykov, T. (2012). Scale construction and development using structural equation modeling. In R. H. Hoyle (Ed.), Handbook of structural equation modeling (pp. 472-492). New York, NY: The Guilford.

Rennie, L. J., \& Parker, L. H. (1997). Students' and teachers' perceptions of single-sex and mixed-sex mathematics classes. Mathematics Education Research Journal, 9(3), 257-273.

Riordan, C. H. (1990). Girls and boys in school: Together or separate? New York: Teachers College Press.

Rosenberg, M. (1986). Conceiving the self. Krieger Malabar, FL: Basic Books,

Rowe, K. J. (1988). Single-sex and mixed-sex classes: The effects of class type on student achievement, confidence and participation in mathematics. Australian Journal of Education, 32(2), 180-202.

Schmitt, N. (1996). Uses and abuses of coefficient alpha. Psychological Assessment, 8(4), 350.

Schoenfeld, A. H. (1985). Mathematical problem solving. New York: Academy Press.

Signorella, M. L., Hayes, A. R., \& Li, Y. (2013). A meta-analytic critique of Mael et al.'s (2005) review of single-sex schooling. Sex Roles, doi: 10.1007/s11199-013-0288-x.

Schriesheim, C. A., Eisenbach, R. J., \& Hill, K. D. (1991). The effect of negation and polar opposite item reversals on questionnaire reliability and validity: An experimental investigation. Educational and Psychological Measurement, 51(1), 67-78.

Schriesheim, C. A., \& Hill, K. D. (1981). Controlling acquiescence response bias by item reversals: The effect on questionnaire validity. Educational and Psychological Measurement, 41(4), 1101-1114. Doi:10.1177/001316448104100420.

Sijtsma, K. (2009). On the use, the misuse, and the very limited usefulness of Cronbach's alpha. Psychometrika, 74(1), 107-120.

Smithers, A., \& Robinson, P. (2006). The paradox of single-sex and co-educational schooling Carmichael Press Buckingham.

Steele, C. M. (1997). A threat in the air: How stereotypes shape intellectual identity and performance. American Psychologist, $52(6), 613$.

Sullivan, A. (2009). Academic self-concept, gender and single-sex schooling. British Educational Research Journal, 35(2), 259-288.

Urbán, R., Szigeti, R., Kökönyei, G., \& Demetrovics, Z. (2014). Global self-esteem and method effects : Competing factor structures, longitudinal invariance, and response styles in adolescents. Behavior Research Methods, 46(2), 488-498. Doi:10.3758/s13428-013-0391-5

Watt, H. M. G., Shapka, J. D., Morris, Z. A., Durik, A. M., Keating, D. P., \& Eccles, J. S. (2012). Gendered motivational processes affecting high school mathematics participation, educational aspirations, and career plans: A comparison of samples from Australia, Canada, and the United States. Developmental Psychology, 48(6), 1594-16611.

West, S. G., Taylor, A. B., \& Wu, W. (2012). Model fit and model selection in structural equation modeling. In R. H. Hoyle (Ed.), Handbook of structural equation modeling (pp. 209-231). New York, NY: The Guilford Press.

\section{End Note}

\footnotetext{
${ }^{1}$ At the time of the questionnaire, Senior Secondary School in Ghana was four years. This present sample was one of the four year groups. Senior Secondary School is now three years.

${ }^{2}$ Seven students in the coed schools did not report their gender. They were excluded from the analysis.

${ }^{3}$ Due to the misunderstanding and confusion surrounding the use, and the misuse of Cronbach's alpha (Sijtsma, 2009), Composite reliability $(\omega)$ was used as a measure of reliability in this study. For discussion on Composite reliability $(\omega)$ and Cronbach's alpha $(\alpha)$, and why the authors preferred $\omega$ to $\alpha$, see Raykov (2012), and Schmitt (1996). Both Composite reliability and Cronbach's alpha are interpreted the same way.

${ }^{4}$ Because of the volume of output, corrected item-total correlations tables are not provided here in but are available from the first author upon request.
} 